\title{
Türk Kamu Yönetiminde Uygulanan Denetim Türlerinin Değişimini Belirleyen Etkenler ${ }^{1}$
}

\author{
Abdulkadir DURSUN 2 \\ Songül ALTINIŞIK ${ }^{3}$
}

\section{Özet}

Bu araștırmada Türk kamu denetim sistemini değişime zorlayan etkenler ile yeniden yapılanma kapsamında Türk kamu denetim sisteminin örgütlenmesi ve işleyişindeki değişimin incelenmesi amaçlanmıştır. Çalışma nitel veri toplama yöntemlerinden olan ve araştırılması hedeflenen konu hakkında bilgi içeren yazılı materyallerin analizini kapsayan doküman analizi (kaynak taramabelge inceleme) yoluyla toplanacak bilgilerin konunun ayrıntılı incelenmesine olanak sağlayacağı düşüncesiyle araştırma, tarama modelinde yapılmıştır. Araştırmada Türk kamu yönetim sistemi ve buna bağlı olarak denetim sistemini değişime zorlayan iç ve diş etkenler ile Türk kamu denetim sisteminde uygulanan denetim türleri incelenmiştir. Türk kamu yönetim ve denetim sisteminin değişime zorlanmasında, özellikle Türkiye'nin Avrupa Birliği (AB), Uluslararası Para Fonu (IMF),Dünya Bankası (WB) gibi uluslararası kuruluşlarla olan ilişkileriyle birlikte, Yeni kamu Yönetimi (YKY) anlayışı başat rol oynamıştır. Bu değişim sonucunda kamu kaynaklarının etkin, verimli ve hesap verilebilir anlayışla kullanılmasını sağlayacak, YKY anlayışı çerçevesinde Türk kamu denetim sisteminin yeninden yapılandırılması beklenmektedir. Türk kamu denetim sisteminde son yıllarda yapılan düzenlemelerle Sayıştay ile yeni oluşturulan kamu denetçiliği (ombudsmanlık)kurumu uluslararası standartlarda yapılandırılmaya çalışılmaktadır. Buna karşılık denetim birimleri ile iç denetim birimlerinin de uluslararası standartlarda yapılandırılması, Kamu İç Mali Kontrol Sisteminin (KİMK) bütünüyle uygulanması için mevzuat düzenlemelerinin yapılması önerilebilir.

Anahtar Kelimeler: Denetim Sistemi, Değişim Etkenleri, Türk Kamu Denetim Türleri

\footnotetext{
${ }^{1} \mathrm{Bu}$ çalışma, TODAİE'de Prof. Dr. Songül ALTINIŞıK danışmanlığında hazırlanan "Uluslararası Denetim Sistemlerindeki Gelişmelerin Türk Kamu Denetimine Yansımaları" adlı tezden yararlanılarak hazırlanmiștır.

2 Maarif Müfettiși, Milli Eğitim Bakanlığı, Türkiye, adursun@meb.gov.tr

3 Prof. Dr. TODAİE Öğretim Üyesi, Türkiye, songulaltinisik@yahoo.com
} 


\title{
Factors That Determine The Inspection Types Applied At The Turkish Public Administration
}

\begin{abstract}
In this study, factors which are forcing Turkish Public Inspection System to change and the change in functioning and organization of Turkish Public Inspection System in the scope of reconstruction are aimed to examine. This study has been done at research and screening model through document analysis (literature-document review) which is One of qualitative data collection methods and covering the analysis of written materials containing information about the intended topics and with the idea that the information to be collected to allow detailed examination. In the research Turkish Public Administration System and accordingly internal and external factors which are forcing Inspection System to change and applied audit types in Turkish Public Inspection System have been examined. In the forcing of Turkish Public Administration and Inspection System to a change especially Turkey's relations with international organizations such as European Union (EU), International Monetary Fund (IMF), World Bank (WB), New Public Administration (NPA) approach has played a dominant role. At the end of this change, reconfiguring of new Turkish Public Inspection System in the framework of NPA approach is expected to provide the use of public resources in effective, efficient and accountable approach. With the regulations in Turkish Inspection Auditing Systems in recent years, newly created Public Auditing (ombudsman) institution with Court of Auditors is trying to be configured in the international standards. In contrast, the configuration of audit units and internal audit units also in the international standards and making of legislations are recommendable for the implementation of all Public Internal Financial Control System (PIFCS).
\end{abstract}

Keywords: Audit System, Change in dicators, Turkish Public Audit Types

\section{Giriş}

Türk kamu yönetim sisteminin işleyişinde karşılaşılan sorunların çözümlenmesi bağlamında, yönetim sisteminin yeniden yapılandırılması sürekli gündemde olmuştur. Bu yapılandırma çalışmaları, 1980 yılına kadar gündelik sorunların çözülmesi şeklinde ortaya çıkmışsa da, Türk kamu yönetim sisteminin sistemsel ve bütünsel anlamda yeniden yapılandırma çalışmaları bu dönemden sonra başlamıştır. Dünyada yaşanan gelişmelere koşut olarak 1980 yılından sonra uygulanmaya çalışılan liberal politikalar, Türk kamu yönetim sisteminin yeniden yapılandırılması için bir başlangıç olmuştur. 
Ancak asıl değişim 1990’lı yılların sonlarına doğru başlamış, bu dönemde iç ve dış dinamiklerin etkisiyle Türk kamu yönetim sistemi ve yönetim sürecinin önemli bir unsuru olan denetim sisteminde de değişim kaçınılmaz olmuştur. Bu değişimde temel olarak rol oynayan etkenler aşağıda başlıklar halinde verilmektedir.

\section{YKY Anlayışı}

Türk kamu yönetim sisteminde değişime olan gereksinimde YKY anlayışının etkisi büyük olmuştur. Bu anlayışla beraber ortaya çıkan ekonomiklik, verimlilik, etkinlik gibi kavramlarla beraber kaliteli ve hızlı kamu yönetimi gerekliliği ortaya çıkmıştır. Bu ilkeler bağlamında etkin bir kamu yönetiminin sağlanması, etkin bir denetim sisteminin kurulmasını zorunlu kılmıştır. Kısaca liberal politikalar sonucunda kamu yönetim alanında meydana gelen değişimle birlikte, denetim sisteminin de yeni bir anlayışla ele alınması gereksinimini ortaya koymuştur.

Kamu yönetiminde, geleneksel yönetim anlayışının yetersiz kalması ve bu anlayışa karşı yapılan eleştiriler sonucunda, YKY anlayışına doğru yaşanan değişimle birlikte, yönetimin önemli süreçlerinden biri olan denetim sisteminin yapısı ve rolü üzerinde de etkili olmuştur. YKY anlayışı çerçevesinde işletmecilik teknik ve uygulamalarının kamu yönetim sistemlerine uygulanması, kamu hizmetlerinin piyasa ile rekabet edebilecek şekilde sunulması, stratejik amaç ve hedefler ile performansa dayalı ve sonuç odaklı yönetim anlayışı, saydam, hesap verebilir ve etkin bir kamu hizmeti sunulması yönündeki gelişmeler, mevcut denetim anlayışını da değişime zorlamıştır. Bu nedenle piyasa ile rekabet edebilen, kurumların stratejik amaç ve hedeflerini azami düzeyde ve sonuç odaklı bir kamu yönetimi anlayışıyla gerçekleștirebilecek yeni bir denetim modeline doğru bir eğilim ortaya çıkmıștır. Kamu hizmetlerinin piyasa temelli yerine getirilmesi ve rekabete açılması, denetimde de anlayış değişikliğini beraberinde getirmiştir. Bu yeni denetim anlayışında, süreçlerden ziyade çıktı ve sonuçların ölçülmesinin önem kazanmasıyla birlikte, etkinlik, verimlilik ve ekonomiklik gibi YKY ilkelerinin de denetimde kullanılmasını zorunlu kılmıştır (Al, 2007: 116-120).

Bununla birlikte kıt olan kamu kaynaklarının etkin, verimli ve ekonomik olarak kullanılması ile kamu yönetiminin saydam ve hesap verebilir bir anlayışıyla işlemesini 
zorunlu kılmıştır. Türkiye'de gelişen demokratik kültür ile birlikte sorumluluk ve hesap verebilirlik anlayıșı da kamu yönetimini değişime zorlamıştır. Demokratik kurumların gelişmesiyle birlikte kamu kaynaklarını kullananların hesap verme gerekliliği ile bilgi iletişim teknolojisindeki gelişmelerle birlikte kamu kaynaklarının kullanılmasında saydamlığın sağlanması yönündeki toplumsal taleplerin artmasına neden olmuştur. Bu hususlar ise denetim sistemini, söz konusu bu kavramlar ve yeni yönetim anlayışı çerçevesinde yeni teknik ve metotlarla yürütülmesine yönelik bir değişime zorlamıștır (Akyel ve Köse; 2010: 13,17).

\section{Mali Sistem Yapısındaki Bozukluklar, Ekonomik Krizler ve Uluslararası} Finans Kuruluşlarının Baskısı

Türk kamu yönetim sistemini değişime zorlayan iç ve dış etkenlerden bir diğeri de, kıt olan kamu kaynaklarının rasyonel bir şekilde kullanılmaması nedeniyle mali sistem üzerinde oluşturduğu yük ve buna bağlı olarak oluşan bütçe açı̆̆ı ile bunun sonucunda meydana gelen ekonomik krizlerdir. Mali sistemin bozulmasıyla oluşan ekonomik krizler, etkin bir kamu yönetimine olan gereksinimi arttırmakta, kamu yönetim sisteminde reform yapılmasında baskı unsuru olarak ortaya çıkmaktadır (Uluğ, 2004: 1-2).

Türkiye'de mali sistemin bozulması, oluşan bütçe açığı ve sonrasında yaşanan ekonomik krizler sonucunda IMF ve Dünya Bankası gibi uluslararası finans kuruluşlarından borç almak zorunda kalınmıştır. Borç almak zorunda kalan Türkiye'nin, kamu açıklarının artmasına ve mali sistemin bozulmasına neden olmuştur. Oluşan kamu açıklarının kapatılması ve mali sistemin düzeltilmesi için, söz konusu kuruluşlarla Türkiye arasında istikrar programları yapılmıştır. Uluslararası finans kuruluşlarıyla yapılan istikrar programları, kamu yönetim sisteminde yapılacak değişiklik şartına bağlanmıştır. $\mathrm{Bu}$ ise Türk kamu yönetim sisteminin değişime zorlanmasında, uluslararası finans kuruluşlarının etkisinin önemli düzeyde gerçekleşmesine neden olmuştur (Dinçer ve Yılmaz, 2003: 57; Uluğ, 2004: 1-2). 


\section{Bilgi İletişim Teknolojisindeki Hızlı Gelişim ve Değişim ile Küreselleşme}

\section{Olgusu}

Kamu yönetim sistemleri üzerindeki değişim etkenlerinden bir diğeri ise, bilgi iletişim teknolojilerinde yaşanan hızlı değişimlerdir. Bilgi teknolojilerindeki bu hızlı değişim neticesinde, ülke kamu yönetimleri üzerinde oluşturduğu değişim baskısından Türk kamu yönetim sistemi de etkilenmiştir. Bu hızlı değişim bireylerin demokratik kültürünün gelişmesine olumlu katkı sağlamasının yanında, kamu hizmetlerinden toplumsal beklentileri de yükseltmiştir. Ancak yükselen bu beklentileri karşılamada Türk kamu yönetim sistemi yeterli performansı gösterememiştir. Bireylerin ve toplumun beklenti ve taleplerine cevap veremeyen ve yeterli performansı gösteremeyen kamu yönetim sistemi yerine katılımcı, şeffaf, hesap verebilir ve daha etkin bir kamu hizmeti için yeniden yapılanma gereksinimi ortaya çıkmıştır.

Bununla birlikte ticaret ve sermayenin küreselleşmesi de, devletin rolü ve işlevini tartışmaya açmıştır. $\mathrm{Bu}$ tartışmalar üreten devlet anlayışı yerine, düzenleyici ve denetleyici işlevi ön planda olan minimal bir devlet yapılanması ihtiyacını ortaya çıkarmıştır. Kısaca işlevi ve rolü değişen devletin geliştireceği politikalarla piyasa ve sivil toplum ağırlıklı hizmet üretimi ve sunumu sağlanırken, sivilleşme ve özelleștirme yönünde gelişen devletin düzenleyici ve denetleyici rolü egemen olmuştur (Dinçer ve Yilmaz, 2003: 26).

\section{Askeri Müdahaleler ile Siyasal İstikrarsızlıklar}

Türk siyasi tarihinde yaşanan askeri darbeler ve müdahaleler Türk kamu yönetim sistemini değişime zorlayan bir başka önemli etken olmuştur. Bu askeri darbeler ve müdahaleler, Türk kamu yönetim sistemi üzerinde zorlayıcı ve düzenleyici şeklinde etkisini göstermiştir (Akbulut vd., 2012: 27).

Bunlarla birlikte Türkiye'deki siyasi istikrarsızlıkta Türk kamu yönetiminin değişime zorlanmasında ve yeniden yapılandırılmasında zorlayıcı bir etki yapmıştır. Türkiye'de yaşanan bu siyasi istikrarsızlıklar bürokrasiyi de etkilemiş, Türk kamu yönetim sisteminin yapılandırılmasında etkili olan bir başka unsur olmuştur. Özellikle 1990’lı yıllardan sonra siyasi istikrarsızlığın devam etmesi ve Türkiye'nin koalisyon 
hükümetleriyle yönetilmesi nedeniyle ortak bir kamu yönetim politikası oluşturulamamıștır. Bu husus ise Türk kamu yönetim sisteminin işleyişini olumsuz yönde etkilemiş, siyasi kurumların sık sık müdahalesine maruz kalan kamu yönetimi, gerektiği şekilde politika üretme ve karar alma yeteneği güçsüzleștirilmiştir (Dinçer ve Yılmaz, 2003: 77).

\section{Türkiye-AB İlişkileri}

Türk kamu yönetim sisteminin değişime zorlanmasında etkili olan bu nedenlerle birlikte, özellikle 2000'li yıllardan sonra Türkiye ve AB arasındaki ilişkiler Türk kamu yönetim ve denetim sistemi üzerinde büyük ölçüde belirleyici olmuştur. Türkiye'nin AB'ye üyelik hedefleri doğrultusunda, birliğin müktesebatına uyum için Türk kamu yönetim ve denetim sisteminde yeniden yapılandırma kaçınılmaz bir zorunluluk haline gelmiş ve bu süreç Türk kamu yönetim ve denetim sisteminin yeniden yapılandırılmasında önemli bir unsur olmuştur. Bu çerçevede son dönemde yapılan yasal düzenlemelerin başında gelen 5018 sayılı KMYKK gelmektedir. Bununla birlikte, meclisten geçtiği halde Cumhurbaşkanı tarafından onaylanmadığı için yürürlüğe girmeyen 5227 sayılı KYTK'da bu yönde yapılan bir diğer önemli düzenleme olmuştur.

\section{6. İnsan Kaynakları Alanındaki Sorunlar ile Merkez-Taşra Arasındaki Görev ve Yetki Dengesizliği}

Türk kamu yönetim sisteminin değişime zorlanmasında etkili olan bu genel nedenlerin dışında, Türkiye'ye özgü başka gerekçeler de bulunmaktadır. Bunların başında kamu kurumlarında istihdam edilen işgücü niteliğinin istenilen düzeyde olmamasıdır. Türk kamu yönetim sistemini değişime zorlayan ve Türkiye’ye özgü bir diğer etken ise, yanlış istihdam politikaları ile bazı kurumlarda aşırı istihdam ile kadrolar şişirilirken, bazı kurumlarda personel açığı bulunmasıdır. Merkez örgütü ile taşra örgütü arasındaki görev ve yetkilerde dengesizlik bulunması, yetkilerin çoğunluğu merkezde toplanmasıyla, taşra örgütlerinde karar alma ve uygulama sistemlerinde yavaşlama da Türk kamu yönetim sisteminin değişime zorlanmasında öne çlkan bir başka gerekçe olmuştur (Uluğ,2004:2). 


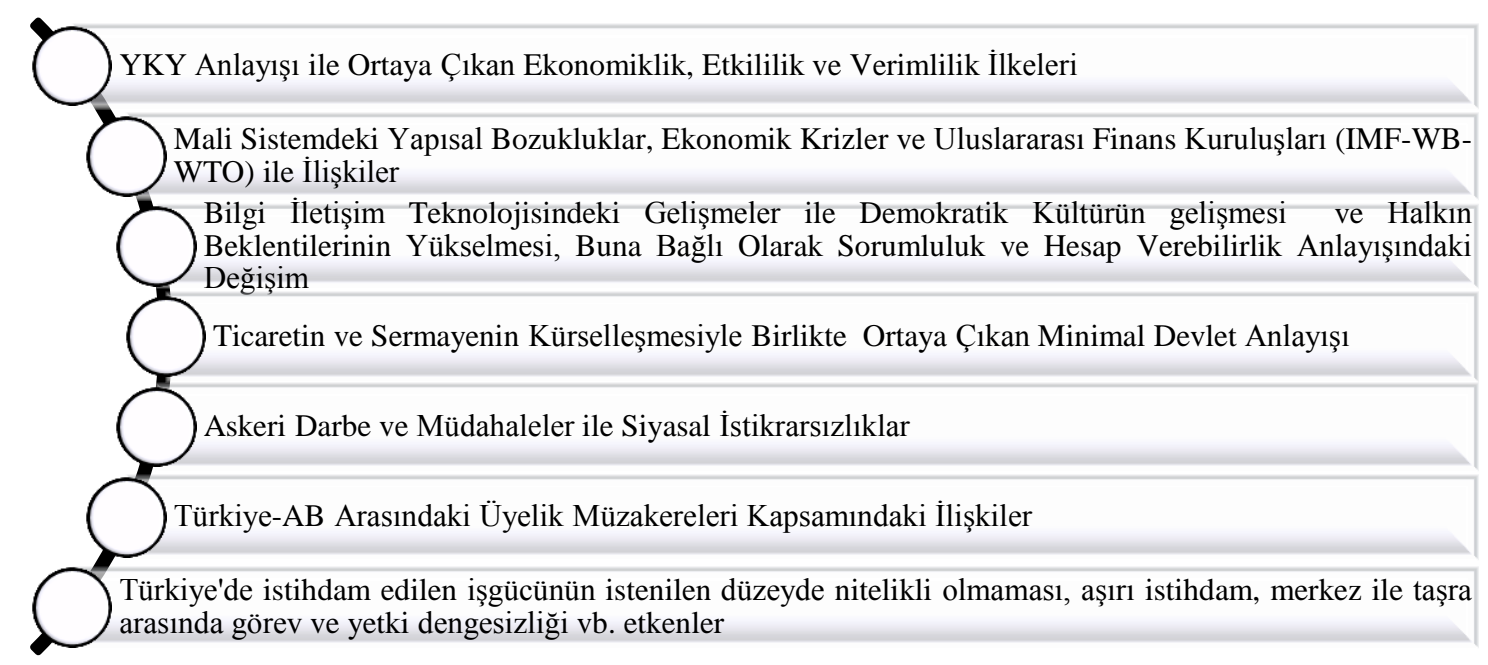

\section{Şekil 1. Türk Kamu Yönetim ve Denetim Sistemindeki Değişimin Etkenleri}

Türk kamu denetim sisteminin değişime zorlanmasında uluslararası gelişmelerle birlikte, kendine özgü nedenlerinde etkisinin olduğu söylenebilir. Yukarıda şekil 2'de görüldüğ̈ üzere, gelişmiş ülke yönetim sistemlerinde YKY anlayışının gelişmesi, Türkiye’nin özellikle mali yapısında yaşanan sıkıntıların sonrasında uluslararası finans kuruluşlarıyla kurulan ilişkiler, bilgi iletişim teknolojisindeki gelişmeler ve buna bağlı olarak toplumun kamu hizmetlerinden beklentilerinin artması, küreselleșme ile birlikte özellikle ticarette sınırların kalkması ve buna bağlı olarak piyasa ile rekabet edilebilmesi için devletin küçültülmesi gereksinimin ortaya çıkması gibi genel nedenlerle birlikte, Türkiye'deki insan kaynakları politikasının yetersizliğinden kaynaklanan nedenler Türk kamu yönetim ve denetim sisteminin yeniden şekillenmesinde belirleyici unsurlar olmuştur. Ancak Türkiye'de özellikle 2000'li yılardan sonra AB ile geliştirdiği ilişkilerde, Türk kamu yönetim ve denetim sistemi üzerinde ana belirleyici unsur olmuştur.

\section{Türk Denetim Sisteminin Örgütlenmesi ve İşleyişindeki Değişim}

Türk kamu yönetim sistemi tümüyle yeni oluşturulmuş bir sistem olmayıp, Osmanlı Devletinin kamu yönetim sisteminde yer alan bazı kurumlar Cumhuriyet döneminde de varlığını devam ettirmiştir. Osmanlı Devletinde özellikle Tanzimat'tan sonra yapılan yenileşme hareketleriyle Osmanlı yönetim sistemi Fransız yönetim sisteminden etkilenmiştir. $\mathrm{Bu}$ etkileşimden yönetim sistemiyle birlikte, yönetimin 
süreçlerinden bir tanesi olan Osmanlı denetim sistemi de payını almıştır. Bu etkileşim sonucunda denetim birimleri olarak teftiş kurulları ortaya çıkmış ve bu ortaya çıkan teftiş kurulları ilk olarak Dışişleri, Maliye ve Adalet Bakanlıklarında kurulmuştur (Köse, 2007: 211).

Daha sonra özellikle Cumhuriyetin kurulmasından sonra oluşturulan yeni Türk kamu yönetim sistemi içerisinde denetim birimleri yer almaya devam etmiş, kurulan Bakanlıklarda Teftiş Kurullarına yer verilmiştir. Türk kamu yönetim sisteminin yeniden yapılandırılması için planlı dönemden önce ve planlı dönemden sonra hazırlanan raporlar, kalkınma planları ile diğer üst politika belgelerinde genellikle kamu yönetim sisteminin bütün olarak yeniden yapılandırılması üzerinde durulmuş, Türk kamu denetim sistemi de bu kapsamda tartışılmıştır.

Türkiye'de kamu denetim sisteminin çok geniş çevrelerde tartışılmış olmasına rağmen 1980 yılına kadar köklü bir reform çalışması yapılmamış, sadece mevzuat değişiklikleri yapmak suretiyle, denetim alanındaki sorunlar çözümlenmeye çalışılmıştır (Köseoğlu, 2007: 312). Bu döneme kadar Türk denetim sisteminde köklü bir değișiklik olmamakla birlikte, 1980'li yıllardan sonra dünyada YKY anlayıșının gelişmesiyle beraber, denetim sistemi anlayışının da değişmesi gereksinimi ortaya çıkmıştır. Bununla birlikte Türk kamu yönetim ve denetim sistemi, YKY anlayışı kapsamında reforma tabi tutulmaya çalışılmıştır. Böylece, Türk kamu yönetiminin denetlenmesine ilişkin anlayış değişikliği 1980’li yıllardan sonra kamu yönetimi alanında yapılan reform çalışmaları belirleyici olmuştur.

$\mathrm{Bu}$ kapsamda, çağdaş denetim sistemlerinde kullanılan etkinlik, verimlilik, tutumluluk kavramları ile performans odaklı denetim anlayışı Türk denetim sisteminde hemen karşılık bulmasa bile, üst politika belgelerinde Türk kamu yönetim sisteminin yapılandırılması başlıklarında özellikle 1990'lı yıllardan sonra yer almaya başlamıştır. Türkiye'de 1994 ekonomik krizi ve 2000'li yılların başındaki ekonomik krizlerle beraber Türk kamu yönetim sisteminin yeniden yaplandırılmasına duyulan ihtiyaç Türk denetim sisteminin örgütlenmesini ve yapılandırılmasını da etkilemiştir.

Son yıllarda yaşanan sosyo ekonomik gelişmeler ile yapılan yapısal reformlar ve demokratik alandaki gelişmelerin etkisiyle de, kamu kaynaklarının harcanmasında hesap verme sorumluluğu anlayışı çerçevesinde bireylerin rolü güçlenmiştir. Bu 
gelişmeler sonucunda Türk denetim sisteminde, çağdaş denetime olan ihtiyaç belirginleşmeye başlamış, girdi odaklı ve cezalandırmaya dayalı denetim anlayışından, rehberlik anlayışı çerçevesinde geliştirici, yol gösterici, performansa dayalı ve sonuç odaklı denetim anlayışına doğru bir dönüşüm yapılmaya çalışılmıştır.

Bu kapsamda özellikle 2000'li yıllardan sonra hazırlanan sekizinci ve dokuzuncu kalkınma planlarında da etkinlik, verimlilik, ekonomiklik anlayışı çerçevesinde saydam, hesap verebilir, hızlı ve kaliteli bir yönetim sistemi kurulması hedeflenmiş, yönetim süreçlerinden bir tanesi olan denetim sistemi de bu hedefler doğrultusunda şekillendirilmeye çalışılmıştır. Türkiye'nin AB'ye katılım girişimleri sonucunda önce aday ülke olarak kabul edilmesi, ardından tam üyelik müzakerelerine başlama tarihi alması sonucunda Türk kamu yönetim sistemi ve buna bağlı olarak denetim sisteminin yapılandırılması üzerinde büyük etkisi olmuştur. Bu etki AB’ye katılım müzakere belgelerinde ve Türkiye ile ilgili olarak hazırlanan ilerleme raporlarında açıkça belirtilmiştir.

Bu kapsamda 2002 yılında iş başına gelen 58. Hükümet tarafından hazırlanan AEP'de belirlenen hedefler doğrultusunda, önce 2003 yılında 5018 sayılı KMYKK meclisten geçerek yasalaşmış ve yürürlüğe girmiștir. Buna paralel olarak 2003 yılında kamuoyu gündemine gelen ve 2004 yılında mecliste yasalaşmasına rağmen zamanın Cumhurbaşkanı tarafından onaylanmadığı için yürürlüğe girmeyen KYTK ile Türk kamu yönetiminin denetlenmesine ilişkin yeni örgütlenme ve sistem değişikliği tasarlanmış, ancak o dönemde uygulama alanı bulamamıștır.

Uygulama alanı bulamayan söz konusu KYTK ile Türkiye'nin, gerek kamu yönetim sistemi ve gerekse denetim sistemi yeni anlayış çerçevesinde şekillendirilmeye çalışılmıştır. Ancak KYTK yürürlüğe girmediği için uygulanamamasına rağmen, daha sonra 2011 yılında çıkarılan KHK'lar ile Bakanlıkların teşkilat yapıları ve bununla birlikte denetim sistemleri söz konusu yasa anlayıșı bağlamında büyük değișikliğe uğramıştır. Bu değişiklik hemen hemen aynı dönemde yapılmasına rağmen, denetim sistemleri için türdeş bir yapı oluşturulamamış ve denetim sistemi karmaşık bir hal almiştır.

Türkiye'de uygulanan diğer denetim türlerinden biri olan yüksek denetim ise, diğer gelişmiş ülkelerde olduğu gibi kamu kurum ve kuruluşları tarafından kullanılan 
kamu kaynaklarının TBMM adına denetimi Sayıştay tarafından yapılmaktadır. Sayıştay Osmanlıda Tanzimat'tan sonra yapılan yenileşme çalışmaları sonucunda 1862 yılında kurulmuş, en son 1982 yılında yapılan Anayasada da yer verilen ve günümüze kadar varlığını devam ettiren Anayasal bir kuruluștur.

Yüksek denetim birimi olan Sayıştay'da yıllar içerisinde değişimden nasibini olmuştur. Türkiye'de yüksek denetim birimi olan Sayıştay, bu isimle ilk defa 1961 Anayasasında yer almış, söz konusu Anayasanın 127. maddesiyle Sayıștay'ın genel ve katma bütçeli dairelerin bütün gelir ve giderleri ile mallarını TBMM adına denetlemek ve sorumluların hesap ve işlemlerini kesin hükme bağlamak ve kanunlarla verilen inceleme, denetleme ve hükme bağlama işlerini yapmakla görevli olduğu hükme bağlanmıştır. Yine aynı Anayasada ifade edilen madde metnine istinaden 1967 tarihinde 832 sayılı Sayıştay kanunu yayımlanmış ve bu kanunla Sayıştay'ın kuruluşu, işleyişi ile görev ve yetkisi ayrıntılı bir şekilde belirlenmiştir.

Sayıştay'ın yapılandırılması kapsamında zaman zaman değişiklikler yapılmış, YKY yönetim anlayışını yansıtan ilk düzenleme 832 sayılı Sayıștay kanununda bazı değişiklikler ile ek maddeler içeren 4149 sayılı kanunla yapılmıştır. Söz konusu kanunla Sayıştay'a, denetimine tabi kurum ve kuruluşlar üzerinde kısmi inceleme ve denetim yetkisi verilmiştir. Bunun dışında, YKY anlayışını yansıtan ve çağdaş denetimin de önemli unsurları olan etkinlik, verimlilik ve tutumluluk kavramları Sayıştay kanununa eklenmiş ve böylece denetime tabi olan kurum ve kuruluşların kamu kaynaklarını etkin, verimli ve tutumlu kullanıp kullanmadıklarını incelemeye Sayıștay yetkili kılınmıștır (4149 Sayılı Kanun, 1996: ek md:9,10; Köse, 2007: 214).

Sayıştay ile ilgili değişim 2000'li yıllardan sonra da devam etmiş, 2003 yılında çıkarılan bir kanunla 832 sayılı Sayıştay kanununda değişiklik yapılmıştır. Bu yeni değişiklik kapsamında Sayıștay'a; TBMM araștırma, soruşturma ve ihtisas komisyonlarının kararına istinaden TBMM Başkanlığının isteği üzerine, denetimine tabi olup olmadığına bakmaksızın özelleştirme, teşvik, borç ve kredi uygulamaları dahil olmak üzere tüm kamu kurum ve kuruluşlarının hesap ve işlemleri ile aynı usule bağlı olarak, kullanılan kamu kaynak ve imkanlarından yararlanma çerçevesinde her türlü kurum, kuruluş, fon, işletme, şirket, kooperatif, birlik, vakıf ve dernekler ile benzeri teşekküllerin hesap ve işlemlerini denetleme yetkisi verilmiştir (4963 Sayılı Kanun, md:7; Köse, 2007: 214). 
Türk kamu mali yönetiminin Sayıştay tarafından denetlenmesinde köklü değişiklikler getiren gelişme 2003 yılında gerçekleşmiştir. Bu çerçevede Türk kamu denetim sistemi anlayışında da çok önemli değişiklikler öngören 5018 sayılı KMYKK yayımlanmıştır. Köse’ye (2007: 214,249) göre, bu kanunla sosyal güvenlik kurumlarının denetimi Sayıştay’a verilmiş ve bu şekilde denetim alanı genişletilmiştir. Bununla birlikte Sayıştay'ın denetim yetkisini sınırlandıran bazı yasal düzenlemeler yürürlükten kaldırılmış, Sayıştay denetiminin yeni teknik ve hedeflerle yürütülmesi benimsenmiştir.

Yine söz konusu KMYKK ile harcama sonrası yapılacak olan dış denetimin Sayıştay tarafından, genel yönetim kapsamındaki kamu idarelerinin hesap verme sorumluluğu kapsamında yaptıkları mali konularla ilgili iş ve işlemlerinin mevzuata, kurumsal amaç ve hedefler ile plan ve programlara uygunluk yönünden incelenmesi ve inceleme sonuçlarının TBMM için raporlanması amacıyla yapılacağı belirtilmiştir. Yine aynı kanunla YKY anlayışını yansıtan etkililik, ekonomiklik, verimlilik, performans gibi kavramlar, Türk kamu yönetim sisteminde ağırlıklı olarak yer almaya başlamıştır. Sayıştay tarafından yapılacak olan dış denetimin; Kamu idarelerinin mali işlemlerinin kanunlara ve hukuka uygun olarak yapılıp yapılmadığının tespit edilmesi ile kamu kaynaklarının etkililik, ekonomiklik ve verimlilik esaslarına uygun kullanılıp kullanılmadığı ile faaliyet sonuçlarının ölçülmesi ve performans değerlendirmesi şeklinde gerçekleştirileceği öngörülmüştür (5018 sayılı Kanun, md: 68).

Sayıştay ile ilgili düzenlemeler bununla sınırlı kalmamış, bu kapsamda çıkarılan "Türkiye Cumhuriyeti Anayasasının Bazı Maddelerinin Değiştirilmesi Hakkında Kanunla" Anayasanın 160. maddesinde hem değişiklik ve hem de söz konusu maddeye ekleme yapılmıştır. Bu düzenlemeye göre, daha önce "genel ve katma bütçeli dairelerin" gelir ve giderleri ile mallarını TBMM adına denetlemek ve sorumluların hesap ve işlemlerini kesin hükme bağlamak ve kanunlarla verilen inceleme, denetleme ve hükme bağlama işlerini yapmakla görevli olan Sayıştay'ın yeni görev alanı merkezî yönetim bütçesi kapsamındaki kamu idareleri ile sosyal güvenlik kurumları şeklinde yeniden belirlenmiştir. Bununla birlikte Mahallî idarelerin hesap ve işlemlerinin denetimi ve kesin hükme bağlanması görevi de yine bu yeni düzenleme kapsamında Sayıștay tarafından yerine getirileceği belirtilmiştir (5428 sayılı Kanun, 2005: md,2; 2709 sayılı Kanun, md: 160). 
Kamu mali denetim sisteminde çok önemli değişiklikler getiren KMYKK ile Sayıştay tarafından yapılacak dış denetimde önemli anlayış değişikliği meydana gelmiştir. Bu anlayış değişikliği sonrasında 1967 yılından beri yürürlükte olan 832 sayılı Sayıştay kanununun değiştirilmesi gereksinimi ortaya çıkmış, bu değişiklik gereksinimi ancak 2010 yılında gerçekleștirilmiştir. Yine bu değişiklik kapsamında TBMM adına KİT’leri denetlemekle görevli olan Başbakanlık Yüksek Denetleme Kurulu kaldırılarak, bu denetim biriminin yetkileri Sayıştay’a devredilmiştir.

Yeni Sayıştay kanunu, hesap verebilirlik ve saydamlık esasları çerçevesinde, kamu idarelerinin etkili, ekonomik, verimli ve hukuka uygun olarak çalışması, her türlü kamu kaynağının amaç, hedef ve diğer tüm hukuki düzenlemelere uygun olarak elde edilmesi, muhafaza edilmesi ve kullanılması için TBMM adına yapılacak denetimlerle, sorumluların hesap ve işlemlerinin kesin hükme bağlanmasını ve kanunlarla verilen inceleme, denetleme ve hükme bağlama işlerini yapmak amacıyla çıkarılmıştır. Bununla birlikte Sayıștay tarafından yapılacak olan denetimin, mali ve uygunluk denetimini kapsayan düzenlilik denetimi ile performans denetimi şeklinde yapılacağı belirtilmiştir (6085 sayılı Kanun, 2010: 1,36).

Sayıştay'ın özellikle 2000’li yıllardan sonra yapılan değişikliklerle, YKY anlayışı kapsamında yapılandırıldığı görülmektedir. Etkinlik, verimlilik, ekonomiklik gibi YKY anlayışını yansıtan kavramların Sayıştay tarafından yapılacak olan denetimlerin temel dayanakları olduğu, özellikle performans denetiminin Sayıștay tarafından yapılacağının en son çıkarılan Sayıștay kanununda yer bulması çağdaş denetim anlayıșını yansıtması bakımından büyük önem arz etmektedir.

Türk kamu denetim sisteminde 2000'li yıllardan sonra yapılan düzenlemelerden bir tanesi de yönetimde şeffaflık ilkesi gereğince Kamuoyu denetimini etkin kılmaya yönelik olarak yapılan yasal düzenlemedir. Bu amaçla kamu kurum ve kuruluşları ile kamu kurumu niteliğindeki meslek kuruluşlarının faaliyetlerinde uygulanmak üzere 2003 yılında Bilgi Edinme Hakkı Kanunu çıkarılmıştır. Söz konusu bu yasayla kurum ve kuruluşlar, yine bu kanunda yazılı istisnalar dışındaki bilgi ve belgeleri, başvuranlara vermekle yükümlü tutulmuştur. Bununla birlikte bilgi ve belgeye erişimin etkin ve hızlı bir şekilde sağlanması için, bireyler tarafından talep edilen bilgi ve belgeye erişimi, kurum ve kuruluşlara belirli bir sürede sağlamaları yükümlülüğü getirilmiştir. Buna göre erişilmek istenen bilgi ve belge talep edilen kurumda ise onbeş gün, kurum 
dışından başka bir birimde ise otuz günlük süre içerisinde sağlanması yasa hükmüne bağlanmıştır. Bununla birlikte bilgi ve belgeye erişim konusunda kurum ve kuruluşlara yapılan başvurularla ilgili olarak yapılacak itirazları değerlendirmek üzere "Bilgi Edinme Değerlendirme Kurulu" oluşturulmuştur (4982 sayılı Kanun, 2003: 1,2,5,11,14).

Dünyada yaygın bir denetim birimi olan "Kamu Denetçiliği” müessesesi ise, Türkiye'de üst politika belgelerinde uzun yıllar yer almasına rağmen, konu ile ilgili düzenleme 2006 yılında yapılmıştır. Ancak Anayasa mahkemesine götürülen söz konusu düzenleme öncelikle 2006 yılında yürürlüğü durdurulmuş, 2008 yılında ise tamamı iptal edilmiştir.

Bu konudaki düzenleme daha sonra 2010 yılında yapılan Anayasa değişikliği ile mümkün olabilmiştir. 1982 Anayasa'sına ek fıkralar eklenerek idarelerin yaptıkları iş ve işlemlerle ilgili olarak gelen şikayetleri incelemek üzere TBMM Başkanlığına bağlı olarak "Kamu Denetçiliği" kurumu kurulmasının yolu açılmıştır. Yine bu düzenleme kapsamında herkesin kamu denetçisine başvurma hakkının olduğu Anayasal teminat altına alınarak "Kamu Denetçiliği Kurumu” kurulmuştur (2709 sayılı Kanun, 2013: md:74). Bu düzenleme ile $\mathrm{ABD}, \mathrm{AB}$ üyesi ülkeler ile birçok gelişmiş ülkede yaygın olan Ombudsmanlık sistemi, yeni bir denetim türü olarak Türk kamu yönetim sistemine eklemlenmesi için bir başlangıç yapılmış oldu.

Kamu Denetçiliği kurumunun kurulması ile ilgili yapılan Anayasa değişikliği sonrasında "Kamu Denetçiliği Kurumu" oluşturmak üzere bir yasa yayımlanmıştır. Yayımlanan bu yasanın amacı bağımsız ve etkin bir şikâyet mekanizması oluşturmak için, idareler tarafından yapılan her türlü iş ve işlemler ile tutum ve davranışlarının insan hakları ve adalet anlayışı ekseninde hukuka ve hakkaniyete uygunluk yönünden incelemek, araştırmak ve önerilerde bulunmak şeklinde belirlenmiş ve bu amaçla "Kamu Denetçiliği Kurumu" oluşturulacağı vurgulanmıştır. Kurumun merkezi Ankara olarak belirlenmiş ve söz konusu bu kuruma gerekli görülen yerlerde büro açma yetkisi verilmiştir. Bununla birlikte idarelerin iș ve işlemleri ile tutum ve davranışları hakkındaki şikâyet başvurularının aracısız olarak doğrudan bu kuruma yapılacağı belirtilmiştir (6328 sayılı Kanun, 2012: md:1,4).

Kamu Denetçiliği Kurumu idarelerin her türlü eylem ve işlemleri ile tutum ve davranışlarını, gelen şikâyetler sonucunda inceleme, araştırma ve öneride bulunma 
hakkı olmasına rağmen, bazı işlemler kurumun görev alanı dışında tutulmuştur. Cumhurbaşkanının tek başına yaptığı işlemler ile resen imzaladığı kararlar ve emirler, yasama yetkisinin kullanılmasına ilişkin işlemler, yargı yetkisinin kullanılmasına ilişkin kararlar ile Türk Silahlı Kuvvetlerinin sırf askerî nitelikteki faaliyetleri kurumun görev alanı dışında tutulan işlemler olarak sayılabilir (6328 sayılı Kanun, 2012: md:5).

Başdenetçi ve denetçilerin meclis tarafından seçilmeleri, bireylerin kuruma doğrudan başvuru haklarının bulunması, yazılı bir dilekçe ile başvurulabildiği gibi elektronik veya diğer iletişim olanaklarıyla başvuru hakkı tanınması olumlu bir gelişmedir. Ancak Başdenetçi ve Denetçilerin iki defa seçilebilmeleri, bağımsızlıkları konusunda bir tereddüt oluşturmaktadır.

\section{Sonuç ve Değerlendirme}

Türk denetim sistemine bakıldığında, aşağıdaki tabloda göründüğü üzere, merkeziyetçi ve parlamenter yönetim sistemine sahip Türkiye'de farklı isimlerle olsa da genellikle Bakanlıkların örgütlenme yapılarında denetim birimlerine yer verildiği görülmektedir. Bununla birlikte Türk kamu yönetim sisteminde AngloSakson denetim modeli olan iç denetim birimleri de, 2003 yılında yayımlanan KMYKK ile yer almaya başlamıştır. Yine söz konusu kanun ile yüksek denetim birimi olan Sayıştay da bu anlayış çerçevesinde yeniden yapılandırılmıştır.

Bununla birlikte gerek 1990’lı yıllardan sonra hazırlanan kalkınma planlarında ve gerekse diğer üst politika belgeleri ile $\mathrm{AB}^{\prime}$ ye üyelik sürecinde yerine getirilmesi gereken yükümlülükler arasında yer alan Kamu Denetçiliği sistemi ise, 2010 yılında yapılan Anayasa değişikliği sonrasında, 2012 yılında çıkarılan Kamu Denetçiliği Kurumu Kanunu ile Türk kamu yönetim sistemi içerisine eklemlenmiştir.

Tablo. Türkiye'de Yönetsel Yapıda Denetim Türleri ve İşlevleri

\begin{tabular}{|c|c|}
\hline $\begin{array}{c}\text { Denetim } \\
\text { Türleri }\end{array}$ & \multicolumn{1}{|c|}{ İşlevleri } \\
\hline Teftiş & $\begin{array}{l}\bullet \text { Bakanlıkların teşkilat yapılarında, Teftiş Kurulu Başkanlığı, } \\
\text { Vergi Denetim Kurulu Başkanlığı, Rehberlik ve Denetim }\end{array}$ \\
\hline
\end{tabular}




\begin{tabular}{|c|c|}
\hline & $\begin{array}{l}\text { Başkanlığı, Rehberlik ve Teftiş Başkanlığl, Denetim } \\
\text { Hizmetleri Başkanlığı, İş Teftiş Kurulu Başkanlığı, Askeri İş } \\
\text { Teftiş Kurulu Başkanlığı } \\
\text { • Başbakanlık teşkilatı içerisinde Başbakanlık Teftiş Kurulu } \\
\text { - Cumhurbaşkanına bağlı Devlet Denetleme Kurulu }\end{array}$ \\
\hline İç Denetim & $\begin{array}{l}\text { • İdarelerde doğrudan en üst yöneticiye bağlı iç denetim } \\
\text { birimi başkanlıkları bulunmaktadır }\end{array}$ \\
\hline $\begin{array}{c}\text { Yüksek } \\
\text { Denetim }\end{array}$ & $\begin{array}{l}\text { - Parlamento adına denetim faaliyetleri Sayıştay tarafından } \\
\text { yerine getirilmektedir. } \\
\text { - Merkezi düzeydedir. }\end{array}$ \\
\hline Ombudsmanlık & $\begin{array}{l}\text { - Kamu idarelerinin iş ve işlemleriyle ilgili şikayetleri } \\
\text { incelemek üzere yasama organına bağlı Kamu Denetçisi } \\
\text { (ombudsman) bulunmaktadır. } \\
\text { - Merkezi düzeydedir } \\
\text { - TBMM tarafından seçilmektedir. } \\
\text { - Bireylerin doğrudan doğruya Kamu Denetçisine başvuru } \\
\text { hakları bulunmaktadır }\end{array}$ \\
\hline
\end{tabular}

Sonuç itibariyle;

- Türk kamu denetim sisteminin yasal statüsü ile denetim birimlerinin görev, yetki ve sorumluluklarını ortaya koyacak, ortak standart oluşturacak genel bir denetim yasasının olmaması,

- Denetim birimleri arasında koordinasyonu sağlayacak bir üst yapının bulunmaması,

- Türk kamu yönetim sisteminde denetim birimleri ile bu birimlerde görevli denetim elemanlarının farklı statü ve isimlerle örgütlendiklerinden, ortak bir denetim sisteminin kurulamaması,

- Genel müfettişlik birimleri ile iç denetim birimleri arasında görev, yetki ve sorumlulukları arasında net bir ayırımın olmaması nedeniyle bu iki denetim birimi arasında görev çakışmasının yaşanması,

- Türk kamu yönetim sistemi büyük ölçüde kıta Avrupası geleneğini temsil eden 
Fransa hukuk ve yönetim sisteminden etkilenmesine rağmen, IMF, WB ve $A B$ gibi uluslararası kuruluşların etkisiyle AngloSakson yönetim sisteminin Türk kamu yönetim sistemine eklemlenmeye çalışılması,

Türk kamu denetim sisteminin yeniden yapılandırılma(ma)sında başat sorunlar olarak sayllabilir.

Buna karşılık;

- Bütün Bakanlıkların teşkilat yapılarındaki denetim birimlerinin başta isimleri ve işlevleri olmak üzere, görev, yetki ve sorumluluklarını düzenleyecek ve ortak bir denetim standardı oluşturacak genel bir denetim yasasının çıkarılması, Başbakanlık Teftiş Kurulu, Bakanlıkların denetim birimleri üzerinde koordinasyonu sağlayacak ve ortak standartlar oluşturacak şekilde yeniden yapılandırılması,

- Genel müfettişlik birimleri ile iç denetim birimleri, birbirlerinin alternatifi olmaktan ziyade birbirlerini tamamlayacak şekilde görev, yetki ve sorumlulukları birbirinden ayrılması ve karşılıklı işbirliği imkânlarının arttırılması,

- Türk kamu yönetim sisteminde, köklü bir geçmişe ve deneyime sahip teftiş birimleriyle birlikte görev, yetki ve sorumlulukları ayırmak suretiyle iç denetim sisteminin görev tanımının yeniden yapılması,

Kurumların kapasitelerine katkı sağlaması açısından yararlı olacaktır. 


\section{Kaynakça:}

- $\quad$ Akbulut, Ö. Ö., Özgen, H. M., Fındık, D., Seymenoğlu, Ö., ve Almış, O. (2012) Türk Kamu Yönetiminde Teftiş ve İç Denetim, Ankara: Türkiye ve Ortadoğu Amme İdaresi Enstitüsü (TODAİE).

- Akyel, R. ve Köse, H. Ö. (Mart 2010) "Kamu Yönetiminde Etkinlik Arayışı:Etkin Kamu Yönetimi İçin Etkin Denetimin Gerekliliği," Türk İdare Dergisi (466), 9-24.

- $\quad$ Al, H. (2007/1) "Denetimde Piyasalaşma Eğilimleri," Bilgi Dergisi (14), 109-130.

- Dinçer, Ö. ve Yılmaz, C. (2003) Değişimin Yönetimi İçin Yönetimde Değişim, Ankara: Başbakanlık.

- Köse, H. (2007) Küreselleşmenin Devlet ve Kamu Yönetimi Üzerindeki Etkileri ve Türk Kamu Yönetimine Yansımaları, Editöler, A. Nohutçu ve A. Balcı içinde, Bilgi Çağında Türk 
Kamu Yönetiminin Yeniden Yapılandırılması-II (s. 1-26), İstanbul: Beta.

- Uluğ, F. (Mart 2004) "Yönetimde Yeniden Yapılanma ve Kamu Yönetimi Temel Kanunu Tasarısı Üzerine Eleștirel Bir Bakış" Amme İdaresi Dergisi, 37 (1), 1-28.

- 2709 Türkiye Cumhuriyeti Anayasası (1982,11 Kasım) T.C. Resmi Gazete, 17863.

- 4149 Sayılı 832 Sayılı Sayıştay Kanunun Bazı Maddelerinin Değiștirilmesine ve Kanuna Bazı Maddeler Eklenmesine Dair Kanun(1996, 4 Temmuz)T.C.Resmi Gazete, 22686.

- 4963 Sayılı Çeşitli Kanunlarda Değişiklik Yapılmasına İlişkin Kanun (2003, 7 Ağustos) T.C. Resmi Gazete, 25192 .

- 4982 Sayılı Bilgi Edinme Hakkı Kanunu (2003, 24 Ekim) T.C. Resmi Gazete, 25269.

- 5018 Sayılı Kamu Mali Yönetimi ve Kontrol Kanunu (2013, 24 Aralık) T.C.Resmi Gazete, 25326.

- 5428 Sayılı Türkiye Cumhuriyeti Anayasasının Bazı Maddelerinin Değiștirilmesi Hakkında Kanun(2005, 9 Kasım) T.C. Resmi Gazete, 25988.

- 6085 Sayılı Sayştay Kanunu (2010, 19 Aralık) T.C. Resmi Gazete, 27790.

- 6328 Sayılı Kamu Denetçiliği Kurumu Kanunu (2012, 29 Haziran) T.C. Resmi Gazete, 28338 